Etnográfica

Revista do Centro em Rede de Investigação em

Antropologia

vol. $22(2) \mid 2018$

Vol. $22(2)$

\title{
Arte colaborativa: uma observação localizada dos teatros e dos seus públicos
}

Collaborative art: a localized observation of theaters and its publics

\section{Vera Borges}

\section{(2) OpenEdition}

\section{Journals}

\section{Edição electrónica}

URL: https://journals.openedition.org/etnografica/5655

DOI: 10.4000/etnografica.5655

ISSN: 2182-2891

\section{Editora}

Centro em Rede de Investigação em Antropologia

\section{Edição impressa}

Data de publição: 1 junho 2018

Paginação: 453-476

ISSN: 0873-6561

\section{Refêrencia eletrónica}

Vera Borges, «Arte colaborativa: uma observação localizada dos teatros e dos seus públicos»,

Etnográfica [Online], vol. 22 (2) | 2018, posto online no dia 07 julho 2018, consultado o 19 janeiro 2022 URL: http://journals.openedition.org/etnografica/5655 ; DOI: https://doi.org/10.4000/etnografica.5655

\section{(c) (i) (8)}

Etnográfica is licensed under a Creative Commons Attribution-NonCommercial 4.0 International License. 


\section{Arte colaborativa: uma observação localizada dos teatros e dos seus públicos}

\section{Vera Borges}

A abertura da arte e das suas estruturas às comunidades locais tem servido para um maior envolvimento dos públicos na cultura e nas decisões que sobre ela são tomadas. As atividades culturais e artísticas são hoje experienciadas como património da terra e representam muito trabalho colaborativo que está para lá das lógicas mais institucionalizadas de reconhecimento da cultura. Neste artigo analisamos três contextos de arte colaborativa e pretendemos extrair os sentidos daquilo que é localmente relevante para os indivíduos. O dinamismo das estruturas, dos artistas-diretores, das equipas e públicos, a sua ligação espontânea e informal, grande proximidade e envolvimento com os públicos merecem um trabalho de campo mais aturado. Procuramos desta forma interpretar as missões de cada estrutura e comunidade, tendo como compromisso a sua observação etnográfica. Esta é reveladora da diversidade de rotinas e ruturas dos quotidianos de trabalho artístico, práticas e interações colaborativas. Veremos que as estruturas que apelam à participação da população local oferecem ao público contextos de convivialidade que podem aumentar o bem-estar de um pequeno círculo de habitantes locais.

PALAVRAS-CHAVE: teatro, arte colaborativa, público, observação etnográfica.

Collaborative art: a localized observation of theaters and its publics - The opening of art and its structures to local communities has been helping to further the public's involvement in culture and in the decisions made about it. Cultural and artistic activities are now experienced as local heritage and they represent a great deal of collaborative work that goes beyond the more institutionalized recognition logic of culture. In this article, we analyze three artistic contexts of collaborative art with the aim of extracting the meaning of what is locally relevant to these people. The dynamism of cultural structures, their artist-directors, teams and publics, their spontaneous and informal networks, proximity and involvement all warrant more in-depth fieldwork. Accordingly, we try to shed light on the missions of each structure and community by means of ethnographic observation. This reveals the diversity of routines and rupture in their day-to-day artistic work, practices and collaborative interactions. We see that the structures which call for the local population's participation provide the public with contexts of conviviality which can enhance the well-being of a small circle of local inhabitants.

KEYWORDS: theater, collaboration, public, ethnographic observation.

BORGES, Vera (vera.borges@iscte-iul.pt) - ISCTE - Instituto Universitário de Lisboa, Dinâmia'CET-IUL; Instituto de Ciências Sociais da Universidade de Lisboa (ICS-ULisboa). 


\section{PREMISSAS, CONTEXTOS E METODOLOGIA}

Na última década e meia, as práticas artísticas de carácter colaborativo intensificaram-se, ampliaram-se e reinventaram-se. ${ }^{1} \mathrm{O}$ fenómeno faz-se a uma escala global e decorre da organização e modos de produção das artes, feitas em conjunto e no interior de intrincadas redes colaborativas e de cooperação (Becker 1960, 1982). Estas redes são alargadas; no entanto, produzem uma ação cada vez mais localizada e comprometida com a terra, com o local. As práticas artísticas colaborativas estão relacionadas com grandes eventos, festivais, bienais e capitais da cultura, mas estão também muito ligadas a programas e projetos de "arte do bairro" (Borges 2015a, 2015b). Em qualquer um dos casos, os seus canais de divulgação e partilha são hoje mais acelerados do que nunca (Kester 2011). Assistimos, desta forma, a uma reconfiguração da relação dos artistas e dos grupos de teatro com os seus públicos. Estes públicos são mais intervenientes e, muitas vezes, assumem-se como fazedores, "cocuradores", de projetos e eventos, desafiando o aparecimento de novos espaços de trabalho e de apresentação, e aceitando participar com os artistas em projetos de forte convivialidade e informalidade, o que os aproxima cada vez mais (Brown, Leonard-Novak e Gilbride 2011; Markusen e Brown 2014; Borges e Lima 2014).

Neste artigo, proponho desvendar três casos e contextos onde práticas e quotidianos deixam ver as artes colaborativas dos nossos dias, nas suas pequenas comunidades, com registos extraídos da minha observação etnográfica e dos diários de bordo que tenho vindo a construir ao longo dos anos (Borges 2001, 2002, 2007, 2015b). Por isso, mais do que fazer a história do trabalho artístico colaborativo ou a história dos teatros na comunidade, sugiro aqui a apresentação de três etnografias com descrições precisas dos contextos onde as mesmas evoluem, se transformam e operam. As descrições que apresento permitem-me, depois, refletir sobre aspetos mais amplos, como as condições de produção da arte e, em particular, do teatro português contemporâneo. ${ }^{2}$

l Este artigo enquadra-se no projeto de investigação intitulado "Reputação, Mercado e Território: Entre o Teatro e a Arquitetura", que tem o apoio da FCT - Fundação para a Ciência e a Tecnologia. O artigo foi parcialmente apresentado no seminário "Criatividade, cultura e território: investigar para/com as comunidades", realizado no Dinâmia'CET-IUL, em Lisboa, no dia 17 de junho de 2015, com o título "Arte colaborativa: organizações, públicos e pequenas comunidades locais". Uma versão alargada do texto foi discutida na Universidade de Leicester, no âmbito da conferência internacional "Is there an alternative? Management after critique", 8-10 de julho de 2015, na linha de pesquisa "Organisation and collaborative practices in the Arts". Agradeço aos colegas os seus comentários e sugestões que enriqueceram este texto.

2 Com a utilização de termos como práticas participativas, colaborativas e relacionais, faço notar que se analisa um conjunto de processos e interações partilhadas que pretendo tratar como formas de uma práxis criativa (ver Kester 2011: 9). Sendo a arte colaborativa um complexo fenómeno cultural com múltiplas genealogias e tendências, a minha preferência será apoiar-me numa análise [continua] 
A formulação das microetnografias que apresento neste artigo inspira-se no trabalho de C. Bastos (2001: 303), cujos pressupostos têm sustentado outras pesquisas, das quais destaco a de F. Rigal (2015) sobre a importância da "densidade do espaço relacional na cidade”. Estas microetnografias de práticas e interações dos protagonistas na sua relação com os territórios vão permitir-me aliar o estudo dos indivíduos às suas interações com os outros e as comunidades, estruturas e contextos locais em que evoluem. Por isso, pedi aos artistas que me falassem sobre os seus espaços de criação, os trabalhos que constroem e as peculiaridades dos territórios onde os produzem. Pedi ainda que me mostrassem aquilo que mais lhes importa na sua relação com esse território e com os seus públicos, que veremos atuar como coparticipantes e criadores de espetáculos, eventos e experiências artísticas.

Procuro, assim, esboçar uma "cartografia de interações" (Bastos 2001: 318) dos artistas e grupos com o seu território e os seus públicos. Nas palavras de J.M. Pais, este dispositivo metodológico entende-se como o momento de o investigador "vaguear nas rotas do quotidiano" (Pais 1993) dos grupos e dos artistas, revelando as suas rotinas, ruturas no trabalho, práticas e interações. É uma análise em modo de descoberta, mais do que a "avassaladora ânsia de possessão" da realidade, de tudo (parecer) conhecer e dominar. A proposta é ultrapassar essa ilusão e promover uma abordagem mais heurística e uma observação que se "aconchega ao calor da intimidade da compreensão" (Pais 1993: 108-1 10). A forma como escrevo e apresento cada um destes três casos e contextos obedece, em certa medida, ao mesmo estilo "retratista" que utilizei em Todos ao Palco! (Borges 2001) e Teatro, Prazer e Risco (Borges 2008).

A minha intenção é mostrar como os indivíduos e os grupos trabalham, apontando acontecimentos, acumulando alguns detalhes de relações e ocorrências que observei e sobre os quais posso generalizar. Como afirmaram Glaser e Strauss (1967: 40): "No trabalho de campo, contudo, as relações são muitas vezes desvendadas in vivo; isso significa que o investigador vê literalmente que estão a ocorrer"; com os sentidos criativamente comprometidos, procuro rever, sentir e transmitir as principais "correspondências" (Pink 2006: 60) do que ali vi acontecer. ${ }^{3}$

Escolhi observar de perto as estruturas culturais Alma d'Arame, em Montemor-o-Novo; a D’Orfeu, em Águeda; e o Teatro Viriato, em Viseu. As estruturas e os seus diretores (A. Anastácio, L. Fernandes, P. Ribeiro) deixaram-me entrar nos seus micromundos das artes, pelo que tenho como ponto de partida a história que me é contada pelo artista-diretor e a observação da sua

das diferentes articulações, práticas e locais da participação e colaboração, e mostrar como podem estes três casos revelar algumas das condições de evolução da arte contemporânea e, em particular, do teatro. 3 Ver também o contributo de Becker et al. (1989) e a forma criativa como apresentam três centros regionais de atividade teatral nos Estados Unidos - Chicago, São Francisco e Mineápolis, recorrendo a um formato de escrita do tipo "texto dramático". 
interação com os indivíduos e as instituições com os quais se cruza no território. Por fim, dou a ver as interseções relacionais que se operam entre os grupos e os seus públicos "escolhidos", sugerindo a importância de que se reveste o seu "chamamento" para a criação conjunta de espetáculos e a sua participação em eventos que associam a arte, promovida pelo grupo, e o seu convívio em redor de experiências que podem ser artístico-gastronómicas.

Em geral, convém sublinhar que, nos três casos, os efeitos do trabalho artístico e cultural desenvolvido pelos grupos não são homogéneos para os seus públicos e comunidades locais; também os benefícios gerados pelo seu trabalho não são lineares, nem estão em direta proporção com a intensidade e o nível de participação dos públicos. As diferentes apropriações territoriais e orientações dos grupos engendram ações artísticas, culturais e sociais distintas, o que constitui o fundamento da minha análise e a escolha intencional destas estruturas. Conjugam-se, com efeito, a observação e análise das vocações, missões e objetivos de indivíduos, mas também de parceiros locais e públicos-participantes, desenhando-se com esta tríade as nossas pequenas comunidades de artes colaborativas.

\section{"A CIDADE COMO UM CONJUNTO":}

\section{ANÁSTÁCIO, ALMA D’ARAME, EM MONTEMOR-O-NOVO}

Entro no centro histórico de Montemor-o-Novo, comunidade intermunicipal do Alentejo Central. Passo pela velha loja do apicultor, as lojas de roupa e lojas -armazém que estão sempre de portas abertas. Ao chegar à estrada principal, aquela que sobe até ao Cineteatro Curvo Semedo, projetado pelo arquiteto Raul Lino, a meio da rua, do lado esquerdo, com uma porta pintada de verde, fica a casa da Alma. ${ }^{4}$ A história do grupo é a mais recente dos três casos analisados. A estrutura foi fundada em 2006 e está sediada nesse prédio antigo, localizado antes do largo onde está o jardim e o coreto.

No primeiro andar do prédio encontra-se a sala de produção e a sala de ensaios do grupo, onde conversei com Anastácio. O grupo concentra nesse espaço a sua equipa de produção. $\mathrm{Na}$ altura, estavam três pessoas, uma das quais trabalha a tempo inteiro no grupo e faz o apoio às atividades administrativas. Numa sala contígua encontram-se as marionetas utilizadas nos espetáculos do grupo, vejo também alguns cartazes e folhetos de divulgação de espetáculos deste e de outros grupos de Lisboa.

A. Anastácio (n. 1972) é cenógrafo e manipulador de marionetas, fundador e diretor da Alma d'Arame. Estreou-se no teatro profissional quando ainda era estudante. Primeiro foi técnico de luz, depois aprendeu a fazer manipulação de marionetas e, no fim da década de 1990, sentiu que era mesmo aquilo que 
queria fazer: "ganhei-lhe o gosto". Esse gosto cresceu enquanto fazia formação na Escola Profissional de Cascais, sob a direção de C. Avillez, encenador e diretor do Teatro Experimental de Cascais. Nesta escola concluiu o curso de cenografia de cena. Em Charleville (França), aprendeu a profissão teatral de ator manipulador.

A Alma d'Arame foi pensada quando Anastácio trabalhava com I. Gama no antigo Teatro de Marionetas de Lisboa. Nesse teatro, conheceu atores manipuladores e recorda os fundadores da Tarumba, grupo de marionetas sediado em Lisboa. Acabaram, no entanto, por seguir outro caminho. A Alma resultou do incentivo de um antigo colega de escola de Anastácio, entretanto vereador da cultura do município de Montemor-o-Novo. Com o passar do tempo, a estrutura formalizou-se e passou a operar de forma mais ativa. Na cidade existem outras estruturas culturais que operam de forma colaborativa, de entre as quais sublinho a ação do Coral de São Domingos, do Ensemble Monte Mor, das Oficinas do Convento, da Rede de Cidadania de Montemor, da Sociedade Antiga Filarmónica Montemorense Carlista, dos Sinais de Fogo e do Chaparro Inquieto.

A primeira atividade produzida pela Alma d'Arame foi um festival. "O festival foi a bandeira do grupo", disse-me Anastácio na nossa primeira conversa [diário de bordo, 22/10/2014]. O festival serviu para "ver como é que as pessoas reagiam. Vamos gastar dinheiro nisto, porquê?" Para ele, o mais importante no trabalho de criação artística são "as pessoas, [elas] são a ignição, o lume, a faísca para fazermos. Não me queixo. Temos salas de 100, 80 pessoas”. Anastácio é reconhecido na cidade pelos seus trabalhos de marionetas, mas acima de tudo atribui o seu reconhecimento ao facto de "pertencer à terra" e de manter uma ligação com as pessoas que ali habitam, os seus vizinhos, o seu público. O festival foi produzido em colaboração com as Oficinas do Convento, uma associação cultural de arte e de comunicação, localizada no Convento de S. Francisco, em Montemor-o-Novo. Anastácio trabalhou nestas Oficinas, na área da produção de espetáculos.

Nas suas palavras, a Alma é hoje um projeto diferente do projeto inicial. Descreve-a como "uma pequena estrutura voltada para o teatro de marionetas, performance, instalação, cenografia, escultura" [diário de bordo, 18/05/2015]. Não se trata apenas de um grupo de teatro de marionetas, o seu trabalho artístico reconfigurou-se e é mais abrangente e interdisciplinar. Afinal, a estrutura situa-se a $101 \mathrm{~km}$ de Lisboa e é envolvida pelos desafios do território onde vive: as marionetas são bem-vindas à terra, mas a ação cultural e a intervenção social que é solicitada ao grupo pelos seus parceiros locais não pode cingir-se apenas a esse tipo de trabalho. A Alma é, mais do que antes, um "corrupio" de

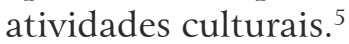

5 O grupo deve o seu nome a António José da Silva, na passagem extraída da "Dedicatória à Mui Nobre Senhora Pecúnia Argentina” (1744), citada no site da estrutura Espaço d'O Tempo, [continua] 
Quando se sai do prédio verde, da Alma, vira-se à direita e chega-se à rua da loja das flores. São flores que enfeitam as paredes da cidade que se parece com um bairro das artes. Seguem-se mais lojas, de comércio variado, e chego a um pequeno café, em frente à escola, acompanhada pelo diretor do grupo, que conversa e fala rapidamente sobre os avanços do seu projeto com a colega do Projeto Ruínas, que também estava em ensaios. Para quem observa, este parece ser um quotidiano de encontros e colaborações muito vivas, que se fazem no dia a dia.

A relação do artista com as outras estruturas e agentes locais tornou-se mais forte desde que a Alma se profissionalizou e passou a "existir" a tempo inteiro. Ali, o trabalho artístico desenvolve-se de uma forma quase circular, porque tudo se concentra num espaço mais ou menos delimitado pelas fronteiras geográficas da própria cidade. A Alma colabora com as Oficinas do Convento e O Espaço d'O Tempo, no Castelo. A O Espaço d'O Tempo foi “difícil chegar", para utilizar as palavras do diretor, mas o grupo foi desenhando o seu caminho, tornando-se um grupo-satélite importante para a colaboração territorial nesta comunidade. A coexistência de inúmeras estruturas culturais e artísticas alimenta as experiências locais e as dinâmicas sociais dos artistas e dos habitantes locais.

Diariamente, Anastácio desmultiplica-se entre as práticas artísticas mais isoladas para pensar o projeto da Alma, as conversas com a equipa mais próxima, a construção e montagem dos espetáculos e a preparação de workshops, passando pelas reunióes com os colegas das estruturas parceiras para afinar a programação conjunta. Mas há ainda tempo para o convívio com os amigos. Amigos que pertencem a organizações comunitárias com as quais Anastácio partilha momentos lúdicos e de cooperação, como acontece, por exemplo, com o projeto de apoio terapêutico a deficientes, Explorar'ARTE, desenvolvido na Casa João Cidade, afastada do centro, junto ao acampamento da comunidade cigana.

Num desses momentos de convívio, ouviu dizer: "sei de um texto que é capaz de te interessar", disse o amigo, professor, reformado [diário de bordo, 18/03/2015]. Estes momentos são a oportunidade de ouvir uma história da terra que pode iniciar uma colaboração espontânea. São momentos de divagação entre quem já se conhece há muito. É que, regra geral, os residentes locais passaram pelo Espaço da Criança. Esse espaço permitiu a Anastácio conhecer outros jovens e estabelecer laços de amizade que permanecem até aos dias de hoje.

Anastácio levou-me ao Espaço da Criança, onde brincou quando era jovem, advertindo-me de que quem visita o espaço "fica comovido". Acontece muito aos artistas estrangeiros que visitam a terra. O Espaço tem pequenas salas onde

[continuação] parceira da Alma: "tudo anda num corrupio... até parece que a alma de arame no corpo da cortiça the infunde verdadeiro espírito e novo alento". Ver: < http://www.oespacodotempo.pt/pt/ comunidade/20/340 > (última consulta em junho de 2018). 
se desenvolvem atividades diversas que ocupam os tempos de lazer das crianças, da pintura, à costura, artes manuais, jogos de computador. É um espaço sem janelas.

Por seu turno, os jovens frequentam o Centro Juvenil. Neste centro há material de costura e lã que ocupa os jovens à conversa. É um espaço de convívio. No fundo, aqueles que agora lideram grupos de teatro e estruturas culturais partilham este passado comum. Anastácio pertence à terra, desde sempre, e essa relação facilita o seu trabalho artístico e a aceitação pelas pessoas da "sua" comunidade.

Como é que Anastácio vê o seu projeto? Ele descreveu-me a Alma como a história de uma estrutura que trabalha "com rede para a consolidação de um projeto para a cidade" [diário de bordo, 22/10/2014]. Com a etiqueta de estrutura que vive nas margens, fora da cidade de Lisboa, esta sua geografia parece afinal dar-lhe mais visibilidade local. No centro de Lisboa acumulam-se estruturas, atividades e artistas. O sentir desse "excesso" foi-me descrito por Anastácio, quando relatou a sua saída do Teatro de Marionetas de Lisboa e a "passagem" pelo Teatro Nacional D. Maria II, no Rossio. Foi uma questão de tempo: Anastácio compreendeu então que Lisboa não era sua.

Já em 2013, através do Projeto M, a Alma participou numa parceria liderada por uma estrutura local mais reconhecida, O Espaço do Tempo, que juntou outros parceiros, como as Oficinas do Convento e o Projeto Ruínas. ${ }^{6}$ Em conjunto, estas estruturas estão associadas ao município. O Projeto M fez-se localmente pela promoção de residências artísticas, workshops e novas criações. O Projeto da Pegada Cultural, que a Alma desenvolveu e coordenou sem outros parceiros, permitiu à equipa consolidar-se e afirmar-se como estrutura programadora de atividades culturais regulares destinadas à população. Foi o caso dos dois workshops a que assisti.

O primeiro foi conduzido por F. Meier, um engenheiro mecânico, alemão, vindo de Lisboa, onde trabalhava na FabLab-EDP. Agora diz-se "rendido a Montemor" [diário de bordo, 22/10/2014], onde vive e trabalha. O workshop dirigiu-se a professores do segundo ciclo. Por seu turno, o segundo workshop destinava-se a ensinar como fazer a caracterização para cinema e tinha como público-alvo jovens-adultos. Foi dirigido pelo norueguês S. Kaarstein. Neste workshop realizavam-se trabalhos com gesso, figuras grotescas, pessoas e animais. Uma dezena de formandos, entre os 20 e os 45 anos, estudantes, educadoras de infância, um marionetista e uma figurinista. Participar nesta atividade visava desenvolver competências, aprender novas técnicas; mas, para os dois últimos (um deles ator-manipulador de profissão) tratou-se de "recordar as técnicas" que tinham deixado de praticar desde que ficaram sem trabalho [diário

6 Este projeto foi financiado no âmbito do acordo tripartido que a DGArtes-SEC celebrou com a Câmara Municipal de Montemor-o-Novo e com O Espaço d'O Tempo e os seus parceiros locais. 
de bordo, 18/03/2015]. Já no workshop “Momentos literários”, escolhido pelo grupo para mostrar o seu público, a Alma recebeu jovens alunos, mostrando-me assim a diversidade de públicos aos quais se dirige e provando que a escola é um dos seus parceiros-chave locais (ver figuras l e 2).

"UMA MALHA TERRITORIAL":

L. FERNANDES, D'ORFEU, EM ÁGUEDA

A minha entrada na D'Orfeu coincidiu com a passagem pelas ruas da baixa de Águeda, ruas repletas de chapéus de chuva abertos, em pleno verão. O efeito é colorido e parece dar as boas-vindas a quem acaba de chegar. Ao fundo, ouvem-se sons de instrumentos. Ouvem-se as crianças que ensaiam no fresco jardim da Casa d'Orfeu. É um espaço amplo, a céu aberto, na altura protegido por uma tenda, onde se reunia a orquestra percussiva da D’Orfeu, a opÁ. O meu compromisso com a observação etnográfica começou neste jardim, com estas crianças e jovens. As crianças preparavam o espetáculo com instrumentos que eram afinal objetos do nosso quotidiano: panelas, colheres, sacos de plástico, latas. Aqui, estes objetos ganharam uma finalidade artística e procuraram reforçar a consciência ecológica dos participantes [diário de bordo, 04/07/2014]. As crianças acabam sempre por tornar-se artistas e protagonistas de um espetáculo nas festas da cidade (ver figura 3 ). ${ }^{7}$

Ao som desta orquestra, com mais de uma centena de crianças e jovens, iniciou-se a nossa conversa, que continuou depois no interior do edifício que visitei com L. Fernandes. A casa é antiga, foi doada aos bombeiros por um particular e, posteriormente, cedida à D'Orfeu. Tem uma pequena biblioteca com um importante espólio documental sobre músicas tradicionais, livros inteiros de história da D'Orfeu, contada em artigos, atas de reuniões e orçamentos. Tem também várias salas de ensaio, uma montra com materiais de divulgação, filmes, DVD para venda. A Casa é ocupada pela equipa de produção e, ao mesmo tempo, pelos jovens, residentes locais, que fazem os seus ensaios. $^{8}$

Fernandes (n. 1972) confessa que se considera um "autodidata da música". Dirige a D'Orfeu porque foi o único que resistiu às suas "travessias difíceis", nos anos 90. Essas travessias devem ter tornado mais forte a sua ligação aos agentes locais, responsáveis pela cultura e capazes de estabelecer laços cooperativos com as instituições na sua envolvente mais ampla, a regional. $\mathrm{Na}$ música, o seu percurso foi "natural". Desde cedo, Fernandes acompanhou os

7 A D'Orfeu situa-se em Águeda (Aveiro), uma região com 11.346 habitantes e $335,27 \mathrm{~km}^{2}$. Mais informação em < https://www.dorfeu.pt/noticias/ > (última consulta em junho de 2018).

8 Em 2014, a D'Orfeu tem 12 trabalhadores a tempo inteiro. Dois desenvolvem o seu estágio profissional. 
quatro irmãos na fundação daquela que era uma escola de música tradicional, em 1995. Os irmãos saíram e Fernandes concluiu a licenciatura em música, na Universidade de Aveiro, no quinto ano da D'Orfeu.

Com o passar do tempo, a estrutura deixou de realizar apenas atividades musicais. Os espetáculos que o grupo tem "em carteira", ou seja, os espetáculos que estão montados para serem vendidos, são músico-teatrais e de novo circo. As atividades que a equipa desenvolve são mais alargadas do que nunca e têm um pendor interassociativo - entre elas os seminários orientados para os ranchos folclóricos e os grupos de teatro amador, versando sobre temáticas como associativismo amador, marketing, gestão, fiscalidade e contabilidade associativa; workshops de dicção e comunicação para o público, em geral, e a orquestra percussiva para os mais jovens, a opÁ.

Como trabalham hoje? E com quem colaboram? Fernandes remete para as semelhanças desta estrutura com a ACERT, localizada em Tondela, Viseu. Porquê? Ele sugere que é o mesmo tipo de trabalho cultural realizado com e para a comunidade, preocupado com o quotidiano local. Nos dois casos, as equipas artísticas e de produção sedimentam o seu trabalho junto dos residentes e mostram-se parceiros-programadores dos seus municípios. O trabalho está ligado à comunidade pelas redes colaborativas primárias que são mobilizadas e que Fernandes me apresentou como sendo uma "curiosidade deste grupo": a D’Orfeu tem sócios cuja participação resulta da sua colaboração direta nas tarefas do grupo e não do pagamento de quotas. O capital social e relacional que Fernandes e a sua equipa foram acumulando, ao longo dos anos, permitiu-lhes consolidar apoios locais que se ampliaram depois com a atribuição de um apoio público central, um importante fator de reconhecimento. ${ }^{9}$

Nas palavras de Fernandes, o apoio do Estado "é a afirmação da força, do crédito do grupo". O diretor entende este apoio institucional como a oportunidade que as estruturas devem aproveitar para se valorizarem na sua terra. Este apoio não é entendido como uma forma de reconhecimento do trabalho artístico que ali se desenvolve, acrescenta. De acordo com as suas palavras, o reconhecimento é feito pela autarquia local e, acima de tudo, pelo seu público, que se "sente chamado" para ver os espetáculos.

O dia a dia de Fernandes é sempre muito intenso: desde a organização de fotografias para divulgar os eventos, espetáculos e festivais, até alimentar a página na Internet, ver o clipping de artigos, áudios e vídeos. O artista tem pouco tempo para criar novos espetáculos, mas há públicos (reais e virtuais) para os apreciar. Por exemplo, a D’Orfeu e o evento "Festim" construíram uma comunidade digital, online, como Fernandes acabou por me mostrar com a sua página da Internet: "Fizemos isto aqui, está registado, chegámos a muitas

9 Trata-se de um acordo tripartido bienal, para o período 2009-2012, estabelecido com a DGArtes-Secretaria de Estado da Cultura. 
pessoas diferentes, partilhámos". ${ }^{10}$ É um modelo de comunicação que anuncia as atividades do grupo e o coloca em diálogo com a sua pequena comunidade local e os seus "seguidores". Mas o nosso dia também avançava.

Preparava-se a chegada e a atuação do último grupo do "Festim". Estava tudo pronto, era só acertar pormenores com a produtora do grupo e partir para o Cineteatro. Viajámos de Águeda até ao Cineteatro de Estarreja. Não chega a uma hora. Mas, pelo caminho, Fernandes mostrou-me a gravação do espetáculo que protagonizara no dia anterior. Foi ator em "Reportório Osório" (ver figura 4). Diz-me que se sente muito recompensado porque "o público participa sempre". E mostra-me que aprecia muito o convívio com os grupos de música internacionais porque o inspiram do ponto de vista artístico.

Quando chegámos, o hall de entrada estava cheio. Vi o público que ocupou a sala do Cineteatro de Estarreja [diário de bordo, 04/07/2014]. Nesse espetáculo, apresentava-se a orquestra ibérica de percussão, Coetus. Os jovens músicos utilizavam instrumentos saídos do quotidiano rural, como os cântaros, os almofarizes ou as frigideiras que transformaram em instrumentos musicais. São utensílios que, ao longo da nossa história, acompanharam procissões, festas e danças na Península Ibérica, como acabaram por me explicar durante o jantar da equipa.

No fim do espetáculo, as famílias estavam muito animadas. Jovens e adultos cumprimentavam o artista-diretor, estão habituados a frequentar o espaço e conhecem a programação. Os filhos convivem na D'Orfeu, nos tempos livres, e depois "trazem os pais ao teatro", como me explicou a mãe de dois jovens da orquestra que ali os acompanhava.

Fernandes considera que o seu modelo de intervenção na cultura local deve ser feito em ligação com a população residente e deve responder às necessidades da região (ver figura 5). O apoio intermunicipal que a estrutura conseguiu consolidar, pela sua associação a seis municípios, resulta da sua conceção de um modelo de programação e um modelo institucional específico que o grupo pensa e reinventa a cada passo com os seus municípios-parceiros.

A este propósito, o jornal da região, Soberania, noticiava assim este festival: "Festim 2014: uma região unida pelas músicas do mundo". ${ }^{11}$ O "Festim" é apresentado como um evento que pretende unir territórios, fazendo a oferta cultural, social e educativa. Mais do que um evento com uma elevada exigência artística, este acontecimento cultural promove momentos de "criatividade ao nível da gestão" e engenharia de programação, de acordo com as palavras do artista-diretor. Depois, o evento permite a sustentabilidade da estrutura e da

10 McCarthy et al. (2004) consideram que fazer, participar, criar um trabalho e partilhá-lo na Internet ativa sentimentos de gratificação e realização individual muito importantes.

11 Reproduzido em < http://dorfeuclipping.blogspot.pt/2014/06/festim-2014-uma-regiao-unida-pela s_4.html > (última consulta em junho de 2018). 
sua equipa artística. Esta equipa pode assim dedicar-se ao seu trabalho artístico, desenvolvendo o "Gesto Orelhudo". Este é, nas palavras de Fernandes, a marca, a identidade artística da estrutura. As ligações internacionais, que começou a explorar com o projeto "OuTonalidades", são outra das vertentes que a D’Orfeu amplia, seguindo a vocação inicial de Fernandes para a música, mas também os interesses dos seus parceiros. Neste projeto, a equipa faz a seleção de candidatos para o seu projeto internacional.

Fernandes cruza, desta forma hábil, engenhosa, sábia, as atividades de criação, programação e difusão, promovendo como prioridade um modelo de "arte com todos" que articula a vocação da estrutura, as trajetórias dos seus profissionais e as características do território e da rede local de parceiros, fortemente ampliada pela sua força digital.

\section{DO "PARTIR XISTO" ATÉ À TENDA DOS SABORES: \\ P. RIBEIRO, TEATRO VIRIATO, EM VISEU}

Ao chegar às imediações do centro histórico de Viseu, vi sem esforço o placard publicitário de grandes dimensões que anunciava o Teatro Viriato e o seu projeto Circus Lab, um conjunto de atividades que integra o programa que construíram para a cidade. ${ }^{12}$ Este placard foi realizado com o apoio da Escola Superior de Tecnologia e tornava visível o projeto na cidade. Já no centro, percorro a sua rua Direita, passo pelas lojas de roupa, artigos de cabeleireiro, lojas das noivas, padarias e, ao fundo desta rua, avisto o Teatro Viriato. Contíguo ao edifício fica o café, muito acolhedor e movimentado, onde se reúnem novos e velhos, um espaço bem vivido pelos habitantes da cidade; depois encontro a placa "Entrada de artistas" e aguardo.

A história do Teatro Viriato é longa e conta-nos que a cidade tinha cinco salas de espetáculos: o Teatro da Rua Escura, o Teatro Paraíso, o Avenida Teatro, o Cine-Rossio e o Teatro Viriato. Depois de 25 anos sem atividade, o Viriato reabriu as portas em 1985, com um projeto artístico da Área Urbana - Núcleo de Ação Cultural e o patrocínio da Fundação Calouste Gulbenkian, o apoio da Câmara Municipal de Viseu e do Governo Civil do Distrito de Viseu: o espetáculo "Teatro de enormidades apenas críveis à luz elétrica", com textos de Aquilino Ribeiro, encenado e interpretado por R. Pais, O. Roriz, L. Madureira, A. Emiliano, com cenário de A. Lagarto e luz de O. Worm.

O projeto de recuperação e reutilização deste teatro foi encomendado à Faculdade de Arquitetura do Porto, sob a orientação do arquiteto Sérgio Fernandez. Entre 1986 e 1996, a Câmara Municipal, em parceria com outras

12 O Teatro Viriato está situado na cidade de Viseu, uma região com 99.274 habitantes e $507,10 \mathrm{~km}^{2}$. A informação sobre a história do teatro encontra-se em < http:/www.teatroviriato.com/pt/menu/teatroviriato/historia $>$ (última consulta em junho de 2018). 
instituições financiadoras, recuperou o teatro. Em 1996, um projeto de programação e administração da Companhia Paulo Ribeiro, com o apoio da Câmara Municipal de Viseu e do então Ministério da Cultura, dá vida ao teatro, originando o Centro de Artes do Espetáculo de Viseu, uma associação cultural e pedagógica. Em 1999 foi inaugurada a primeira temporada da nova vida do Viriato, com a apresentação do espetáculo remontado para a ocasião "Raízes rurais, paixões urbanas", de R. Pais - cujo título descreve bem o contexto em que o Viriato se insere. Entre 2003 e 2006, o Viriato foi dirigido por M. Honrado, quando P. Ribeiro assumiu a direção artística do Ballet Gulbenkian.

P. Ribeiro (n. 1955) é coreógrafo e diretor da companhia de dança com o seu nome. Nasceu em Lisboa e, no princípio da sua carreira, trabalhou como bailarino, na Bélgica e em França. A estreia na criação coreográfica fez-se em 1984, em Paris, na companhia Stridanse. P. Ribeiro foi galardoado com vários prémios internacionais - prémio de Humor em 1984, 2. ${ }^{\circ}$ prémio de Dança Contemporânea, no Concurso Volinine, em 1985 - e nacionais - o Prémio Acarte pela obra "Dançar Cabo Verde", em 1994. ${ }^{13}$ Entre 1998 e 2003, foi o diretor-geral e de programação do Teatro Viriato/Centro Regional das Artes do Espetáculo das Beiras. Em 2003, tornou-se o diretor artístico do Ballet Gulbenkian, fundado em 1965 e extinto em 2005.

Em 2015, a Companhia Paulo Ribeiro celebra 20 anos de atividade. A trajetória do seu diretor é marcada pelo seu reconhecimento. A minha conversa com Ribeiro foi iniciada no átrio do Teatro Viriato, depois de uma conversa e alguns contactos com P. Garcia, diretora de produção. O diretor-coreógrafo passou pela escola de dança Lugar Presente, ali mesmo ao lado, para ver se estava tudo bem. Eu visitei os bastidores do teatro, que ainda cheiram a novo, e a sala de ensaios onde P. Ribeiro trabalha e constrói os seus espetáculos com os bailarinos. A sala é impressionante: muito ampla, com muita luz e uma vista inspiradora para a cidade [diário de bordo, 19/05/2015]. Estava ocupada por uma equipa de atores em residência artística no Teatro Viriato.

$\mathrm{Na}$ sala de produção de J. Fernandes, e agora os três reunidos, P. Ribeiro começou de uma forma divertida: “... a minha sala é demasiado desorganizada para lá se entrar!” A nossa conversa foi o momento para a equipa refletir sobre o culminar de um percurso individual e o trabalho de programação desenvolvido em equipa, no Viriato. Registo, no entanto, a sua nostalgia por um tempo que não chama os seus bailarinos e a sua dança, mas escolhe apenas alguns,

13 Destacam-se os seguintes prémios: "Prix d'Auteur", nos V Rencontres Chorégraphiques Internationales de Seine Saint-Denis, (França); "New Coreography Award”, atribuído pelo Bonnie Bird Fund-Laban Centre (Grã-Bretanha); "Prix d'Interprétation Collective", atribuído pela ADAMI (França); Prémio Bordalo 2001; Prémio Almada, do Instituto Português das Artes do Espetáculo, atribuído ao Viriato, pela atividade desenvolvida na área da dança. 
disse. Depois, uma reflexão sobre a sua (perfeita, pelo menos afigura-se-me assim) colaboração com os outros dois responsáveis pelos destinos do teatro: P. Garcia e J. Fernandes.

Ribeiro falou sobre a confiança que as instituições locais foram criando em torno de si e da sua equipa. Descreveu a entrada na cidade de Viseu, apoiando-se no sentimento que recorda ter resultado da colaboração inicial com as entidades locais. "Foi como partir xisto", disse Ribeiro, recorrendo à metáfora da pedra predominante na região para desvendar os seus primeiros encontros. Foi "partir xisto" de forma quase natural, pedindo colaboração, apoios e conseguindo criar um ambiente de confiança, uma rede de apoio. Na terra não o conheciam pessoalmente, era um artista de Lisboa. Aceitou o desafio, mas não tinha qualquer ligação profissional a Viseu. Hoje, admite que ainda gosta da experiência de viver em Viseu, mas precisa sempre de sair, de visitar e ver o que se passa nas grandes cidades, por isso está quase semanalmente em Lisboa, para assistir aos espetáculos e participar na vida cultural da cidade.

O Teatro Viriato tem a residência permanente da Companhia Paulo Ribeiro, que faz criação e itinerância de espetáculos - a cidade de Paris continua a ser o seu destino privilegiado - e desenvolve trabalho pedagógico. Desde 2004, a escola de dança Lugar Presente ocupa as instalações contíguas ao Viriato, num edifício recuperado e cedido pela Câmara Municipal de Viseu e pela Santa Casa da Misericórdia de Viseu. A escola oferece aulas de ensino artístico especializado: cursos de iniciação à dança, curso básico e secundário de dança, cursos livres, em Viseu. A ligação da escola ao Teatro Viriato vai aprofundar-se com a participação dos alunos em workshops de formação no espaço de trabalho, dirigidos pelos professores e técnicos do teatro. A direção pedagógica considera a hipótese de os jovens frequentarem workshops técnicos no teatro, uma vez que as experiências artísticas e técnicas são indissociáveis: “eu acompanho os miúdos, e daqui a sete, oito anos, podem integrar uma produção da companhia", acrescentou P. Ribeiro.

A forma como a estrutura vai evoluindo na cidade é vivida com reconhecimento mútuo dos artistas e dos habitantes. Atravessei a rua Direita e perguntei onde ficava o teatro. Avaliei facilmente que este é conhecido pelos residentes, que indicam com entusiasmo o edifício. "Não era assim há uns anos", confessou P. Ribeiro. A relação com a cidade pautou-se inicialmente pela "cautela", nas suas palavras. "No princípio arriscávamos muito pouco em coproduções, era sempre um risco, normalmente a programação era feita com rede", disse Ribeiro. Hoje, as colaborações com as outras estruturas e instituições locais tornam o Teatro Viriato um caso de sucesso. P. Garcia relembrou que a forma como o Viriato está hoje "dentro" da cidade deve muito à boa relação com as escolas. Essa relação tem um passado que descreveu assim: "é como um percurso, entrámos pela escola, depois no contexto de sala de aula e, hoje, somos cúmplices" (ver figuras 5-7). 
O Teatro Viriato tem também capacidade para apoiar e receber outros artistas e estruturas que, no panorama teatral português, são mais flutuantes, sem espaço para trabalhar, mas encontrando aqui uma relação colaborativa importante. Desta forma, parece proporcionar-se à comunidade de Viseu e Dão Lafões, a realização de inúmeras atividades culturais e o convite ao seu público, muitas vezes partilhado com a ACERT (Tondela): “[os nossos] têm sido projetos pensados de raiz. Há espetáculos que circulam pela ACERT, mas a [nossa] companhia não vai a Tondela. Há cruzamento de públicos e não tanto de espetáculos", conclui Ribeiro.

O projeto Circus Lab promove uma rede colaborativa de vários municípios (Viseu, Mangualde, Nelas, São Pedro do Sul e Tondela) e prevê a criação artística, em parceria com a ACERT (Tondela), mas também a Binaural/Nodar (São Pedro do Sul), a Companhia Paulo Ribeiro (Viseu), a Erva Daninha (Porto) e a Radar $360^{\circ}$ (Porto), com a Escola Secundária Viriato (Viseu), o Agrupamento de Escolas de Tondela Tomaz Ribeiro e o Agrupamento de Escolas de São Pedro do Sul. Os processos artísticos culminam com a apresentação dos resultados nas escolas, junto dos alunos, e no Teatro Viriato. Segue-se uma conferência internacional sobre a importância do ensino artístico no ensino obrigatório. ${ }^{14}$ Mas o programa artístico e cultural é muito diversificado, inclui espetáculos e oficinas e a Tenda de Sabores. São as experiências gastronómicas que chamam o público em geral. E quem é, afinal, o público do Viriato? São as crianças, a partir dos três anos, os jovens e os adultos. P. Ribeiro fala-me, com profunda emoção, daquela gratificação intrínseca que incentiva todos os artistas a continuar o seu trabalho: "À noite é fantástico. Quando desafiamos é bonito ver a forma como as pessoas confiam... Estava cheio!"

\section{DISCUSSÃO CRÍTICA COMPARATIVA}

Para complementar as observações anteriores, solicitei a cada um dos três grupos que selecionasse (em duas ou três fotografias) os seus públicos, encontrando em H. Becker a discussão que me permite dar aqui sentido ao uso destas fotografias (Becker 1986: 232, 1998). É que nas escolhas, feitas pelos três grupos, podemos ver a diversidade dos seus públicos e os trabalhos que desenvolvem, mas podemos também vislumbrar e experienciar os contextos em que estes espetáculos foram produzidos, os modelos de divulgação que cada organização cultural desenvolve (o fotógrafo de cena é mais procurado nos dois últimos casos), a sua estética e as linhas programáticas que estão subjacentes a cada uma das estruturas.

14 Previa-se que a conferência decorresse no Centro Cultural Vila Flor, em Guimarães, e n'O Espaço do Tempo, em Montemor-o-Novo, em 2015. 


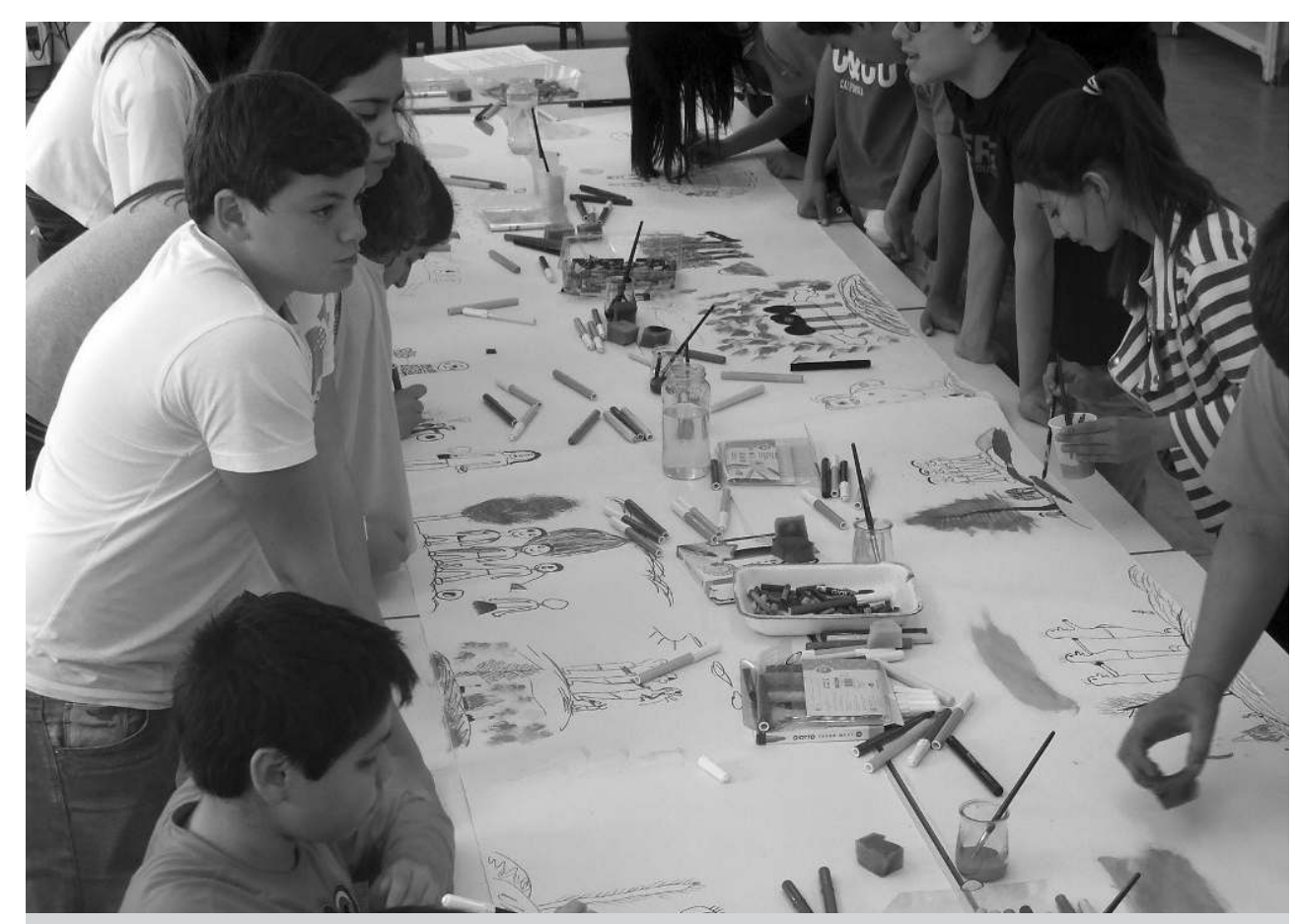

Figuras 1 e 2 - “Momentos literários”, EB 2,3, Montemor-o-Novo, 10/03/2015. @ Alma d'Arame.

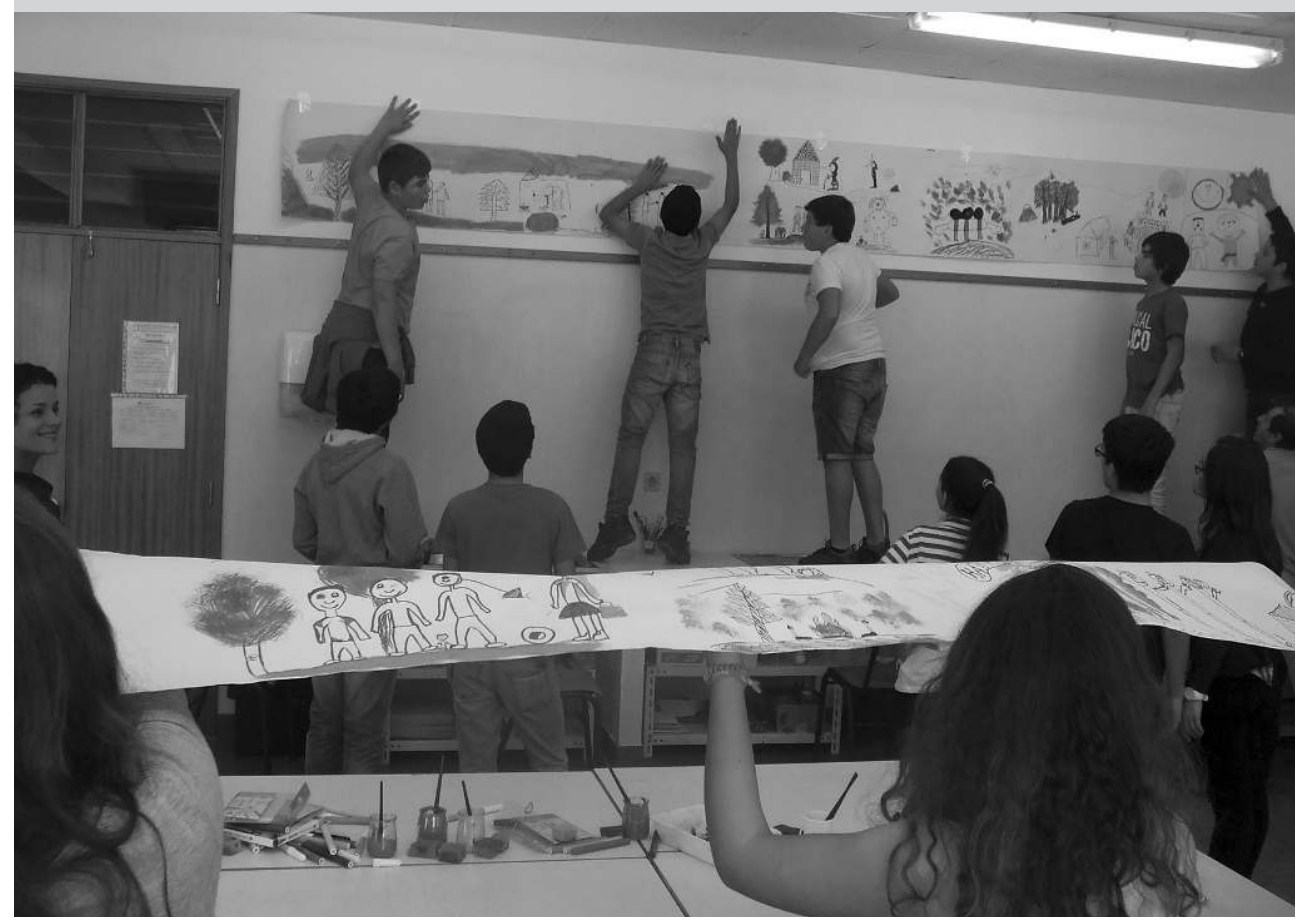




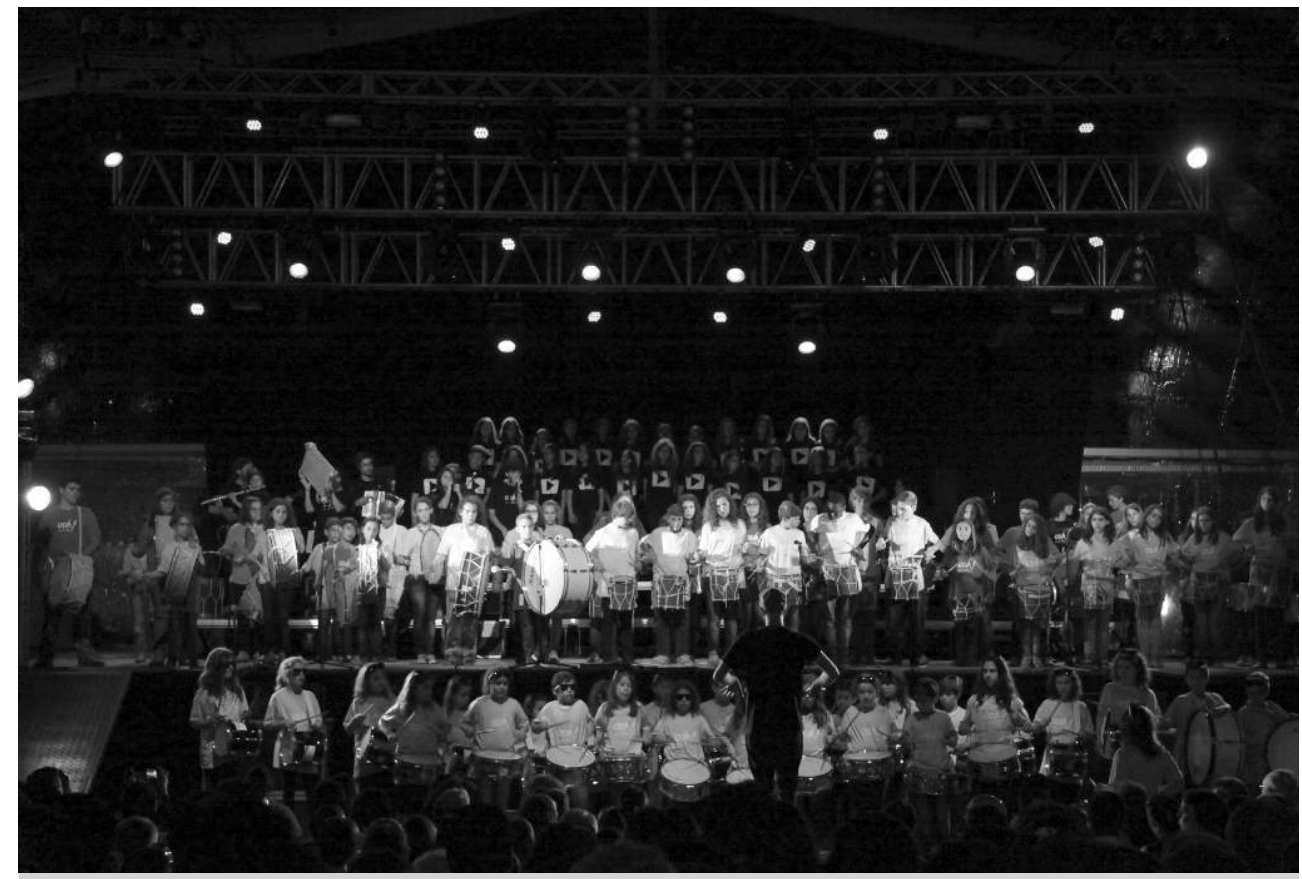

Figura 3 - D’Orfeu, Orquestra Percussiva de Águeda, AgitÁgueda, 09/07/2014. (c) MárioAbreu.

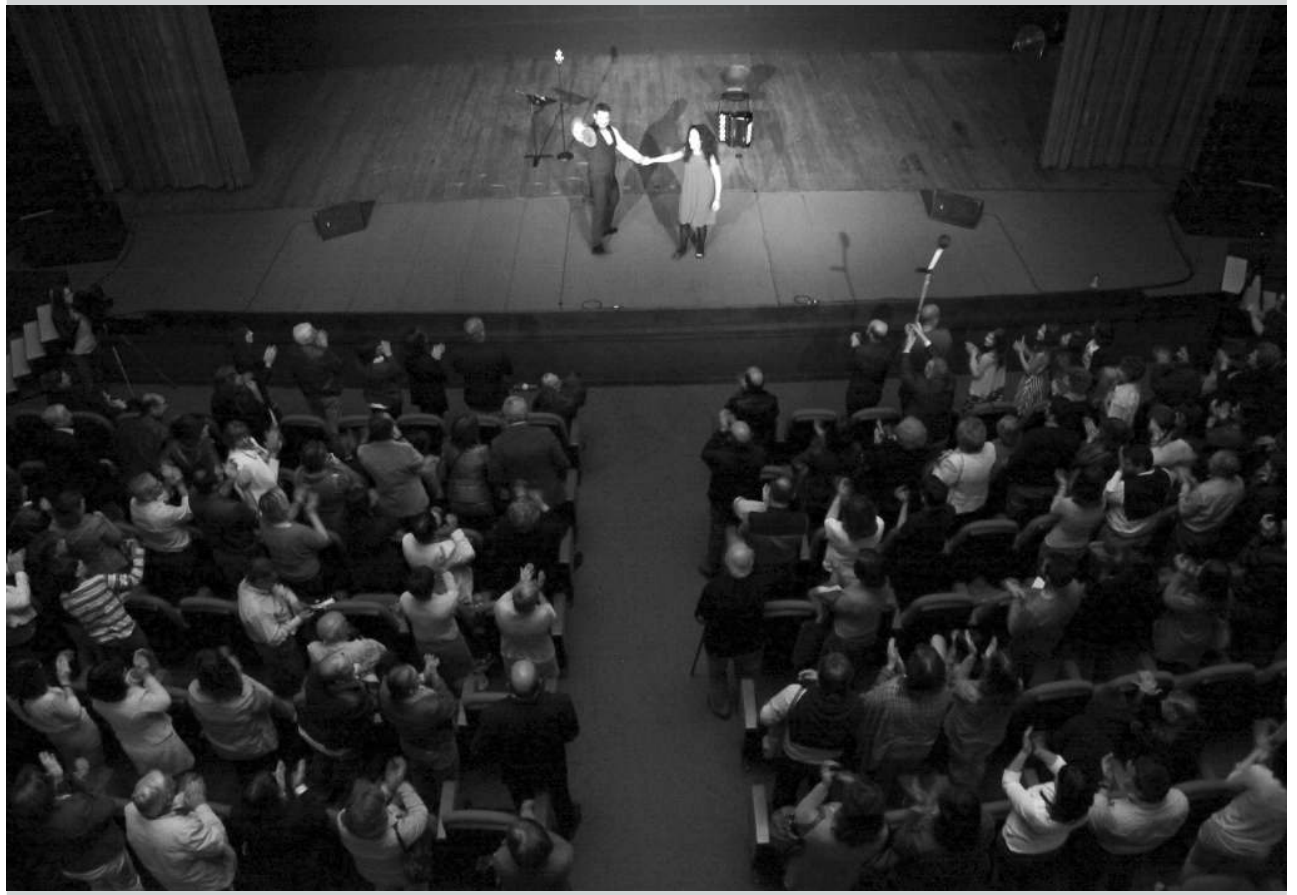

Figura 4 - "Reportório Osório", Sextas Culturais@ Cineteatro São Pedro, Águeda, 09/05/2014. @ MárioAbreu. 
No primeiro caso, Alma d'Arame, mostrei que o seu artista-diretor, A. Anastácio, mantém uma relação informal com os parceiros locais, as diferentes organizações artísticas, socioculturais e terapêuticas: "são todos da terra". Além disso, a estrutura está situada num território cuja geografia promove a convivência de artistas profissionais e amadores com a população vizinha. É um grupo com uma prática artística transdisciplinar, sendo o diretor reconhecido pelo público, não pela marca autoral dos espetáculos produzidos, mas sim pela relação de compromisso com o local, com os parceiros culturais e com os seus públicos participantes, como as crianças, os jovens e os professores (ver figura 1).

No segundo caso, a D'Orfeu, apresentei a forma como o artista-diretor trabalha para a comunidade local, nomeadamente para as crianças e os jovens que frequentam a Casa depois da escola, e mostrei como esse trabalho ganha visibilidade com a participação dos jovens na Orquestra Percussiva de Águeda. $\mathrm{Na}$ figura 3, os jovens atuam no "AgitÁgueda Art Festival", evento organizado pelo município, com a intenção de promover o turismo e a fruição dos espaços públicos. É de sublinhar a colaboração direta dos habitantes locais nas atividades associativas do grupo e nos festivais que o mesmo organiza, como o "Festim". Recordo as palavras de L. Fernandes sobre um anúncio feito no "Festim": "Experimentem o festival no seu interior, liguem-se ao grupo". É um modelo que dá prioridade à consolidação regional do grupo, numa comunidade que o diretor conhece e para a qual orienta os projetos da D'Orfeu. Por fim, a figura 4 mostra a outra dimensão do seu trabalho: o diretor é o ator em "Reportório Osório", espetáculo apresentado no Cineteatro São Pedro. Nesta foto vê-se o público a aplaudir de pé o seu espetáculo de teatro musical.

No terceiro caso, o Teatro Viriato teve, nos últimos 16 anos, a direção de um reconhecido coreógrafo, $\mathrm{P}$. Ribeiro. $\mathrm{O}$ teatro está situado num território onde o número de organizações profissionais e amadoras locais se desenvolve e evolui constantemente. A equipa da direção mantém relações profissionais e institucionais muito sólidas com o município, bem como parcerias com outras instituições culturais e escolas. Procura ainda abrir as suas atividades às crianças mais pequenas e às suas famílias, como se pode ver nas fotos das figuras 5 e 6. Mostrei que, neste caso, o teatro alimenta uma relação profissional com a escola de dança, criada pelo diretor, e acolhe residências artísticas de grupos vindos de Lisboa. O diretor procura, desta forma, alargar e dar visibilidade nacional à comunidade para a qual trabalha. Na figura 7, o seu Circus Lab Open é um exemplo das dinâmicas colaborativas e da condição relacional dos jovens que habitam este espaço urbano.

Nas três microetnografias apresentadas não prevalece a ideia do artista-criador-diretor voltado unicamente para o seu trabalho artístico. É a "qualidade da experiência" (Dewey 2005 [1934]: 50-51), daqueles que concebem e participam nestes projetos, o mais importante. Essa experiência assegura valores 


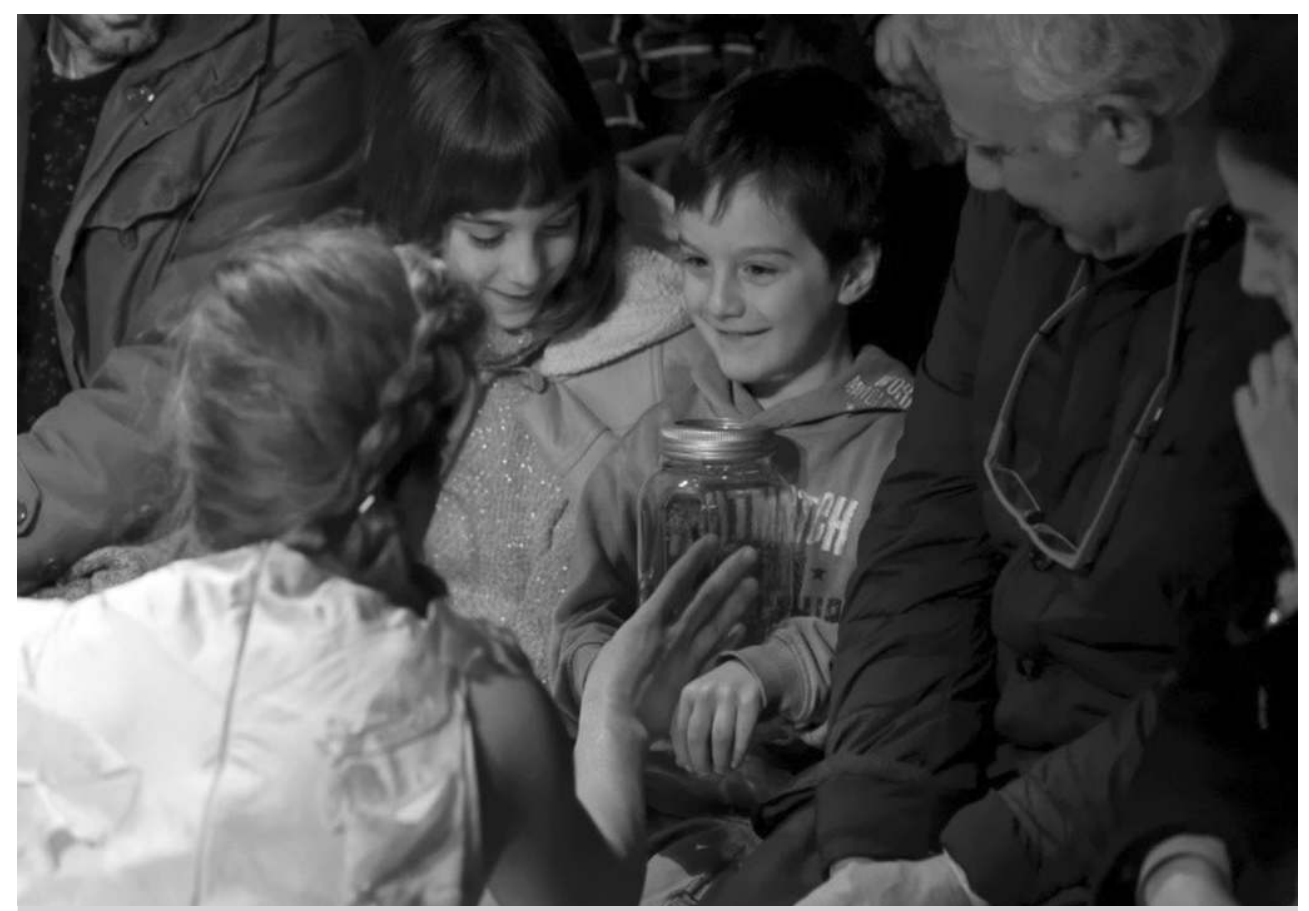

Figura 5 - Teatro Viriato, Circus Lab, Viseu, Ambar, 22/05/2015.

(c) José Alfredo.

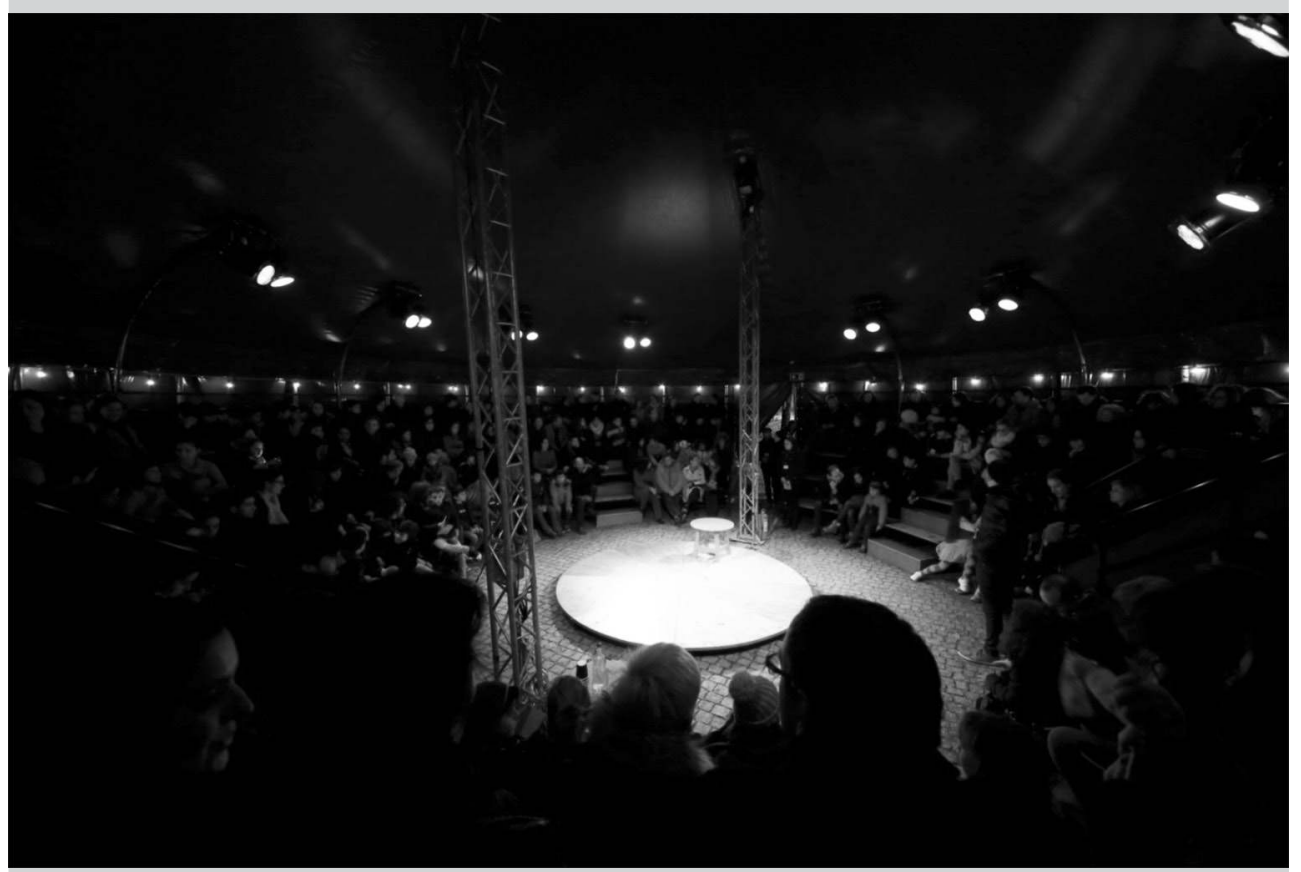

Figura 6 - Teatro Viriato, Circus Lab/Bibeu \& Humphrey, Viseu, 17/02/2015. () José Alfredo. 


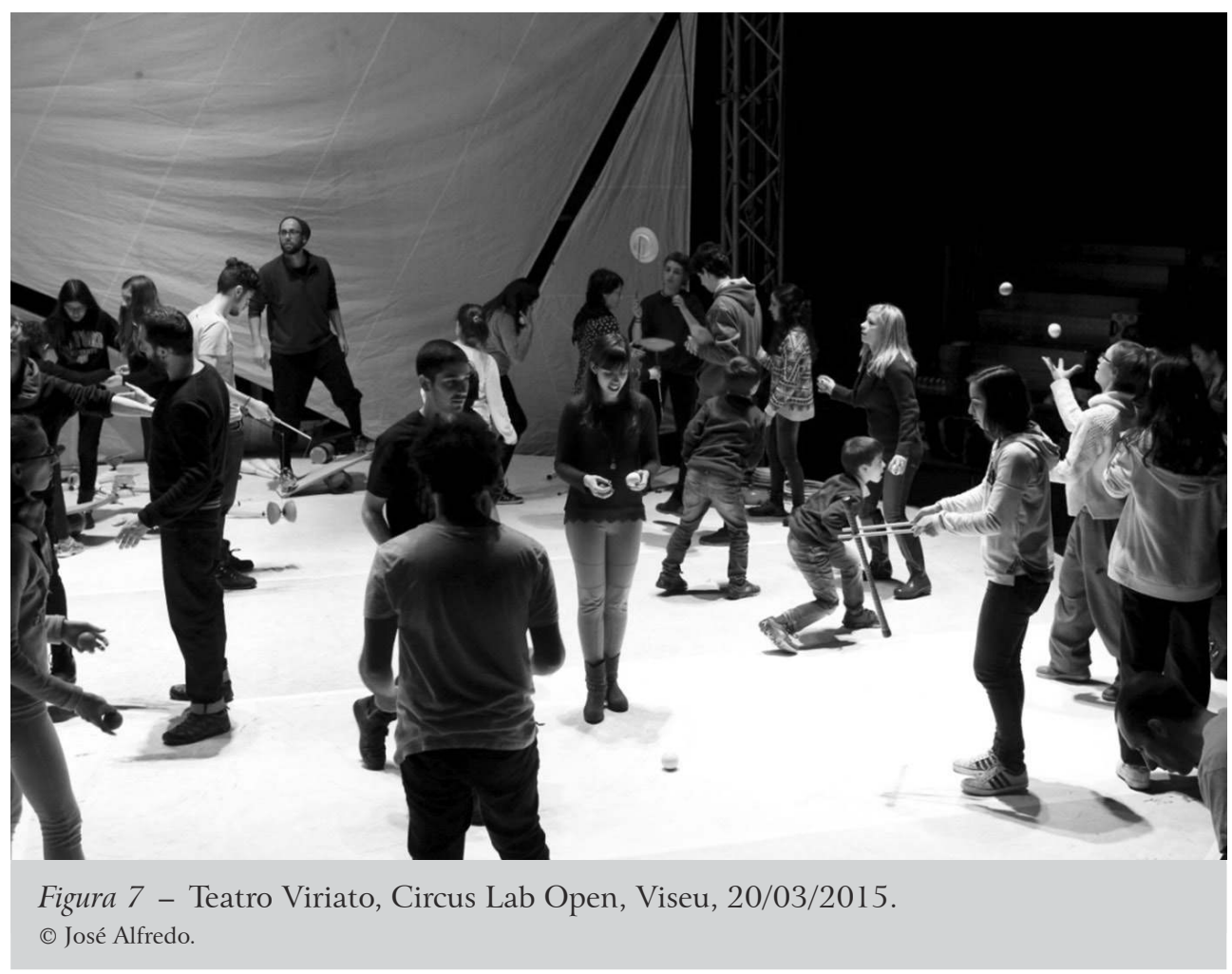

e sentidos partilhados que fazem progredir a esfera pública e um pequeno "círculo" de habitantes locais que acompanha e participa nas atividades das estruturas: por exemplo, o avô e a criança (figura 5) no circo, ou os jovens que experimentam técnicas do novo circo, no Teatro Viriato, são disso mesmo um bom exemplo (figura 7). Já a forma como os três grupos gerem a componente artística, cultural e social de cada projeto, e de cada teatro, é diversa.

Os grupos ou estruturas culturais como a Alma d'Arame, a D'Orfeu e o Teatro Viriato são diferentes, como são diversas as trajetórias dos seus profissionais, os espaços (teatros) que ocupam, os territórios que habitam, os propósitos estéticos e artísticos dos diretores, as forças institucionais que intervêm localmente e os seus públicos, embora haja um ethos e uma prática comum que passa pela colaboração dos seus públicos locais. Para alguns são os seminários e workshops mais desligados da atuação artística das suas equipas, momentos de partilha de experiências culturais com a população e os conhecidos/vizinhos do grupo; para outros, os workshops funcionam como ateliers de criação artística que aumentam as interações criativas da comunidade e dos seus artistas.

Depois, devemos ainda notar que, nos três casos, a "permeabilidade da arte é adjacente a outras formas de produção simbólica (urbanismo, ativismo ambiental, trabalho social, etc.)" (Kester 2011: 7) - do ativismo cívico ao 
participar-fazendo, à educação pela arte, à arte e comunhão. Esta comunhão pode ser feita à volta de uma mesa e proporcionar a convivência entre os indivíduos, por exemplo, através da "arte" e das experiências gastronómicas, como a degustação do melhor da região de Viseu e dos países-parceiros do teatro, como a Noruega, no caso do Teatro Viriato.

Neste sentido, as finalidades e consequências mais profundas destes workshops, ateliers, projetos, eventos, espetáculos, feitos com e para a comunidade - a que chamámos "teatro com todos" (Borges 2015a) - estão longe de ficar inteiramente desvendadas. Mas, de forma resumida, pode considerar-se desde já que, enquanto mobilizadores de pequenas comunidades, estes grupos dão visibilidade à arte e ao local. Fazem-no alimentando diariamente as suas atividades na comunidade, na região, mas também utilizando as redes digitais, construindo uma comunidade digital e reinventando-se nela, sobretudo no caso da D’Orfeu. Deste modo, fazer "artes" é também estar conectado (ver, a propósito deste tema, Gauntlett 2011). Por fim, destaco nesta discussão alguns pontos que considero centrais para o estudo das artes colaborativas e do teatro português contemporâneo, tendo em conta os três contextos apresentados e a literatura produzida sobre a temática:

- O teatro deu lugar a práticas artísticas que se apoiam cada vez mais em conceitos alargados sobre aquilo que é a arte, aumentando ainda o número de pessoas interessadas e a sua diversidade social. A oferta de atividades é coerente com as necessidades locais e a sua pertinência é diferente de um território para outro, como mostrei com os três casos. Algumas das práticas artísticas são workshops. Estes representam ateliers de criação que juntam indivíduos com diferentes formações. No caso do Teatro Viriato, apresenta-se, paralelamente ao programa de espetáculos e ateliers, um conjunto de palestras cuja discussão é alargada a outras comunidades e cidades do país.

- A proliferação da arte colaborativa (pela qual estes três contextos foram influenciados) sugere as transformações que vão ocorrendo na natureza da prática artística contemporânea. Apresentei experiências culturais e artísticas locais cujas missões são exemplos bem-sucedidos da participação dos indivíduos e do trabalho das estruturas nos territórios onde se localizam. Respondem assim aos interesses dos residentes e a novos desafios artísticos, como aqueles trazidos pelo novo circo que se instalou em Viseu (no Teatro Viriato) ou os workshops digitais e de máscaras feitos com a população local de Montemor-o-Novo (com a Alma d'Arame).

- A inovação é a chave da criação artística, mas é hoje um conceito mais amplo do que nunca. Não se trata muitas vezes de inovação artística, mas inovação no tipo de gestão, difusão e espetacularização dos eventos. Por exemplo, é de notar que existem práticas artísticas que exploram 
melhor as tecnologias digitais, fazendo aumentar a visibilidade de algumas experiências e eventos/festivais da terra, fortalecendo o diálogo com a sua comunidade digital e ampliando a sua visibilidade nacional.

- Os processos e as negociações mantidas entre as estruturas e os poderes locais mostram que é possível trabalhar em conjunto, promovendo contextos de arte colaborativa com interesse - como também mostrou Comunian (2011) com o estudo de caso que realizou em Inglaterra. O envolvimento destas três estruturas com os parceiros locais - que, como se viu pela cartografia de interações dos três diretores, ultrapassa a esfera pessoal - é forte e capaz de desenvolver a atividade cultural de uma, ou mais, comunidades intermunicipais, dando acesso a outras formas culturais (a orquestra da D’Orfeu, em Águeda, é disso um bom exemplo). Muitas destas estruturas são parceiras dos municípios também para programar nos cineteatros mais próximos. Não fazem funcionar plenamente esses cineteatros, por falta de meios ou porque não são esses os objetivos dos intervenientes locais na gestão cultural; no entanto, colaboram e são exemplos de formas de gestão multilocais que são ensaiadas e põem a funcionar os teatros (como acontece com a D'Orfeu).

\section{CONSIDERAÇÕES FINAIS}

Neste artigo procurou-se "vaguear" por três contextos e fazer a descrição compreensiva destes casos, desvendando práticas, interações e quotidianos (Pais 1993; Bastos 2001). Imbuídos numa geografia cultural diferenciada, os três contextos mostram equipas capazes de manter e criar uma ligação profunda com o seu território e o seu público. Em qualquer um dos três casos, os teatros e os seus públicos, artistas e estruturas estão a fazer a sua "arte" assente em práticas participativas, de convivência, socialmente comprometidas com o território e com a comunidade local (Borges 2015a). A amplitude geográfica da ação destes grupos tem vindo a alargar-se de forma promissora: as comunidades alargaram o escopo das atividades consideradas culturais, ampliaram a definição de cultura que estavam dispostas a proporcionar aos habitantes, tornando-a mais antropológica, diversa em função dos públicos, "articulando política cultural com educação, política urbana e social” (Menger 2010: 10).

O que há de comum nas microetnografias de interações que apresentei é o envolvimento de parceiros - criadores, equipas, municípios, públicos (crianças, jovens e adultos) -, estimulando-se a sua participação e o seu convívio com a população local. É a cultura da participação e da experiência. Nesta pesquisa, verificou-se que os princípios de sustentabilidade e as novas práticas artísticas fazem a ponte entre o aprofundamento daquela que é a identidade local, mais tradicional, no território onde operam e a contemporaneidade, num contexto cada vez mais global, aproximando-se desta forma a população das suas raízes 
ao mesmo tempo que se inunda com novos conceitos e artes: da orquestra que constrói instrumentos com objetos do quotidiano e mistura de reportório do cancioneiro tradicional de Águeda com as expressões rítmicas contemporâneas, às tendas do chapitô, em Viseu, onde se apresenta e debate o que de mais recente se sabe sobre o novo circo, o desenvolvimento de novas linguagens, até chegarmos à Tenda de Sabores, que à noite reúne todos para as experiências gastronómicas da região e do país parceiro, a Noruega, passando ainda pelo associativismo de Montemor-o-Novo, e da Alma d'Arame como elo agregador de estruturas locais profissionais e amadoras.

Os três grupos desenvolvem práticas institucionais mais abertas e promovem uma arte mais colaborativa que cruza áreas artísticas como o teatro, a música, as artes visuais, a dança, o circo. Nos dois últimos casos, a relação entre a gestão, a produção, a difusão e, até certo ponto, a espetacularização da cultura é mais forte. No fundo, o que os grupos de teatro fazem no seu território é uma (nova) avaliação daquilo que pode ser a cultura, ligando essa nova leitura à necessidade de os seus públicos participarem, ocuparem os seus tempos livres (no caso das crianças e dos idosos), mas também à necessidade de os artistas se reinventarem nas suas carreiras profissionais. Trata-se, pois, de reconhecer neste conjunto de experiências, propostas pelos grupos à comunidade local e ao seu público, que as suas preocupações não são apenas artísticas, mas asseguram e consolidam a posição dos grupos num território específico. Depois, as peculiaridades dos próprios territórios e dos seus habitantes modelam e estruturam essas práticas criativas, a sua mediação cultural e, por fim, o sucesso dos projetos.

É assim que vemos aliar-se à ideia de práticas artísticas e culturais “da nossa terra" a ideia de sustentabilidade, vivência de uma cidadania ativa, que aponta para a ligação entre a identidade tradicional local e o mundo global, onde a informação e a divulgação do trabalho artístico online tão bem servem, afinal, a interação e a participação das pessoas. Faz-se teatro de marionetas, constroem-se máscaras ou monstros gigantes, na Alma d'Arame; mistura-se o reportório tradicional com expressões rítmicas mais contemporâneas, na D’Orfeu; ou praticam-se técnicas de novo circo, no Teatro Viriato. Faz-se uma arte que se comenta e discute, o que resulta em "benefícios intrínsecos" já estudados (Brown e Leonard-Novak 2007). Descobrem-se novas vocações dos artistas e grupos, novos espaços e tempos de convívio. Faz-se mais "teatro com todos", com impacto na qualidade de vida de um pequeno círculo de habitantes locais.

É por isso que se torna cada mais instigante analisar estes processos e discutir as nossas metodologias (Borges, Costa e Graça 2014), pois afinal não estamos sempre a analisar objetos, performances e espetáculos. Casos, contextos, conjunturas, dimensões processuais são fundamentos da nossa análise social das artes e do nosso compromisso com a sua observação etnográfica. 


\section{BIBLIOGRAFIA}

BASTOS, Cristiana, 2001, "Omulu em Lisboa: etnografias para uma teoria da globalização", Etnográfica, V (2): 303-324, disponível em < http://ceas.iscte.pt/etnografica/docs/vol_05/ N2/Vol_v_N2_303-324.pdf > (última consulta em junho de 2018).

BECKER, Howard S., 1960, "Notes on the concept of commitment", The American Journal of Sociology, 66: 32-40.

BECKER, Howard S., 1982, Art Worlds. Berkeley, University of California Press.

BECKER, Howard S., 1986, Doing Things Together: Selected Papers. Evanston, IL, Nothwestern University Press, 223-271.

BECKER, Howard S., 1998, "Categories and comparisons: how we find meaning in photographs”, Visual Anthropology Review, 14: 3-10.

BECKER, Howard S., et al., 1989, “Theatres and communities: three scenes”, Social Problems, 36 (2): 93-116.

BORGES, Vera, 2001, Todos ao Palco! Estudos Sociológicos sobre o Teatro em Portugal. Oeiras, Celta Editora.

BORGES, Vera, 2002, "Artistas em rede ou artistas sem rede? Reflexões sobre o teatro em Portugal", Sociologia, Problemas e Práticas, 40: 87-106.

BORgeS, Vera, 2007, O Mundo do Teatro em Portugal. Lisboa, Imprensa de Ciências Sociais.

BOrges, Vera, 2008, Teatro, Prazer e Risco: Retratos Sociológicos de Actores e Encenadores Portugueses. Lisboa, Roma Editora.

BORGES, Vera, 2015a, "Teatro com todos", JL, Jornal de Artes, Letras e Ideias, dossiê "Tiago Rodrigues e o novo teatro português", 8 de setembro, disponível em < http://visao.sapo. $\mathrm{pt} /$ jornaldeletras/teatroedanca/teatro-com-todos $=\mathrm{f} 830615>$ (última consulta em junho de 2018).

BORGES, Vera, 2015b, "Le théâtre se fait dans le quartier: une étude des troupes portugaises à vocation locale", Revue Registres, 18: 54-64.

BORGES, Vera, Pedro COSTA, e Susana GRAÇA, 2014, "Trabalhar n(os) grupos de teatro: das potencialidades e desafios de uma investigação nas artes”, Análise Social, XLIX (213): 955-968.

BORGES, Vera, e Tiago LIMA, 2014, "Apoio público, reconhecimento e organizações culturais: o caso do teatro", Análise Social, XLIX (213): 926-952.

BROWN, Alan S., e Jennifer LEONARD-NOVAK, 2007, Assessing the Intrinsic Impacts of a Live Performance. S.l., Wolf Brown, disponível em < http://wolfbrown.com/images/books_rep orts/documents/ImpactStudyFinalVersionFullReport.pdf $>$ (última consulta em junho de 2018).

BROWN, Alan S., Jennifer LEONARD-NOVAK, e Shelly GILBRIDE, 2011 , Getting In On the Act: How Art Groups Are Creating Opportunities for Active Participation. São Francisco, The James Irvine Foundation, disponível em < https://irvine-dot-org.s3.amazonaws.com/doc uments/12/attachments/GettingInOntheAct2014_DEC3.pdf > (última consulta em junho de 2018).

COMUNIAN, Roberta, 2011 , "Rethinking the creative city: the role of complexity, networks and interactions in the urban creative economy", Urban Studies, 48 (6): 1157-1179, DOI: $10.1177 / 0042098010370626$.

DEWEY, John, 2005 [1934], Art as Experience. Nova Iorque, Perigee, DOI: 10.1177/00380 38505050540 . 
GAUNTLETT, David, 2011 , Making is Connecting: The Social Meaning of Creativity, from DIY and Knitting to YouTube and Web 2.0. Cambridge, Polity Press.

GLASER, Barney, e Anselm STRAUSS, 1967, The Discovery of Grounded Theory: Strategies for Qualitative Research. Chicago, Aldine Publishing Company.

KESTER, Grant H., 2011, The One and the Many: Contemporary Collaborative Art in a Global Context. Durham, NC, Duke University Press.

MARKUSEN, Ann, e Alan BROWN, 2014, "From audience to participants: new thinking for the performing arts", Análise Social, XLIX (213): 866-883.

McCARTHY, Kevin F., et al., 2004, Gifts of the Muse: Reframing the Debate about the Benefits of the Arts. Santa Monica, CA, Rand Corporation, disponível em < http://www.rand.org/ content/dam/rand/pubs/monographs/2005/RAND_MG218.pdf > (última consulta em junho de 2018).

MENGER, Pierre-Michel, 2010, "Cultural policies in Europe: from a state to a city-centered perspective on cultural generativity”, GRIPS Discussion Paper 10-28, disponível em < http://www3.grips.ac.jp/ pinc/data/10-28.pdf > (última consulta em junho de 2018). PAIS, José Machado, 1993, "Nas rotas do quotidiano", Revista Crítica de Ciências Sociais, 37 : 105-1 15, disponível em < http://www.ces.uc.pt/publicacoes/rccs/artigos/37/Jose\%20Mac hado\%20Pais\%20-\%20Nas\%20Rotas\%20do\%20Quotidiano.pdf > (última consulta em junho de 2018).

PINK, Sarah, 2006, The Future of Visual Anthropology: Engaging the Senses. Londres, Routledge. RIGAL, Francis, 2015, "La ville dans la ville: sur la densité relationnelle d'un espace public à Lisbonne”, Etnográfica, 19 (1): 99-120, DOI: 10.4000/etnografica.3920 (última consulta em junho de 2018).

$\begin{array}{ll}\text { Receção da versão original / Original version } & 2016 / 08 / 22 \\ \text { Receção da versão revista / Revised version } & 2017 / 04 / 27 \\ \text { Aceitação / Accepted } & 2018 / 05 / 15\end{array}$

